\title{
Pengaruh Umur Panen Terhadap Kandungan Zat Gizi Biji Dua Varietas Kacang Tanah (Arachis hypogaea L.)
}

\section{The Influence of Harvest Time on Seed Nutrition Content of Two Varieties of Peanut (Arachis hypogaea L.)}

\section{Astuti Hertiningsih}

Fakultas Pertanian, Universitas Sarjanawiyata Tamansiswa, Yogyakarta

\begin{abstract}
The objectives of the research is to study the influence of harvest time on seed nutrition content of two varieties of peanut. The varieties of peanust are Gajah and Local varieties. The harvest was divided into eight time differences, as follow: 26, 31, 36, 41, 46, 51, 56 and 61 days after flowering. The seed nutrition was measured as carbohydrate, protein, lipid and water content. The data were analyzed by Anova and DMRT, and quadratic regression. The research showed that nutrition content of seed is influenced by the time of harvest.
\end{abstract}

Key words: peanut, harvest time, nutrition. content

Diterima: 21 Oktober 2002, disetujui 20 April 2003

\section{Pendahuluan}

Kacang tanah merupakan salah satu tanaman palawija yang pertumbuhannya terdiri atas fase vegetatif dan fase generatif. Fase vegetatif dimulai sejak perkecambahan hingga awal pembungaan. Fase generatif dimulai sejak timbulnya bunga pertama sampai polong masak, dan dicirikan dengan adanya bunga, buah, dan biji. Boote (1982 cit. Trustinah, 1993) membagi fase reproduktif kacang tanah menjadi 9 stadia, yaitu mulai berbunga $\left(R_{1}\right)$, pembentukan ginofor $\left(\mathrm{R}_{2}\right)$, pembentukan polong $\left(\mathrm{R}_{3}\right)$, polong penuh $\left(\mathrm{R}_{4}\right)$, pembentukan biji $\left(\mathrm{R}_{5}\right)$, biji penuh $\left(\mathrm{R}_{6}\right)$, biji mulai masak $\left(\mathrm{R}_{7}\right)$, masak panen $\left(\mathrm{R}_{8}\right)$, dan polong lewat panen $\left(\mathrm{R}_{9}\right)$. Perkembangan biji dimulai dengan stadia pembentukan biji $\left(R_{5}\right)$, kurang lebih 26 hari setelah tanaman berbunga, atau tiga minggu setelah ginofor masuk tanah. Setelah itu diikuti dengan tahap selanjutnya.

Makanan cadangan utama yang tersimpan dalam biji adalah karbohidrat, protein, dan lemak. Menurut Woodroof (1983), kandungan karbohidrat biji kacang tanah kurang lebih $21 \%$, protein $28 \%$, dan lemak 44$58 \%$. Komposisi gizi tersebut dapat berbeda antara satu varietas dengan varietas yang lain, bahkan pada lingkungan hidup yang sama. Penelitian ini bertujuan untuk mengetahui kandungan gizi biji kacang tanah yang dipanen pada umur-umur tertentu.

\section{Metode Penelitian}

Percobaan dilaksanakan di Kebun Percobaan Agronomi, Wonocatur, Banguntapan, Yogyakarta. Analisis zat gizi dilakukan di laboratorium Pengolahan Hasil Pertanian, Fakultas Teknologi Pertanian, Universitas Gadjah Mada Yogyakarta.

Percobaan ini menggunakan metoda Split Plot dengan 3 ulangan. Main plotnya adalah varietas, yaitu varietas Gajah dan Lokal, sedangkan sub plotnya adalah umur panen biji, yaitu 26, 31, 36, 41, 46, 51, 56, dan 61 hari setelah berbunga (HSB). Dimulai umur 26 hari, karena diperkirakan pembentukan polong telah selesai dan mulai pembentukan biji (Trustinah, 1993). 
Analisis kimia berupa analisis kadar air, lemak, protein, dan karbohidrat. Data yang diperoleh dianalisis dengan anova pada taraf 5 $\%$, dan dilanjutkan uji Duncan pada taraf $5 \%$. Adanya hubungan umur biji dengan zat gizi dianalisis menggunakan persamaan regresi kuadratik (Gomez and Gomez, 1983).

\section{Hasil dan Pembahasan}

Hasil pengamatan di laboratorium menunjukkan adanya peningkatan kadar air yang mencapai puncaknya pada umur 36 dan 41 hari setelah tanaman berbunga (Tabel 1), lalu cenderung turun sampai akhir pemanenan. Berdasar analisis statistik, perbedaan kadar air tidak terjadi pada kedua varietas, tetapi pada faktor umur panen. Umumnya, pada tanaman legume, embryosac yang sedang mengalami proses fertilisasi mempunyai kadar air yang tinggi, yang akan menurun dengan bertambahnya umur biji, sampai menjadi kurang lebih $20 \%$ menjelang pemasakan biji. Penelitian Chamma et al. (1990) menunjukkan adanya penurunan kadar air pada biji buncis mulai umur 67 hari sampai 101 hari, dari $60 \%$ menjadi $19 \%$. Hal ini disebabkan pada proses fotosintesis, air dan karbondioksida diubah menjadi berat kering biji maupun bagian tanaman lainnya. Pembentukan ini berlangsung sampai pemasakan biji.

Kadar air biji penting artinya dalam menetapkan waktu panen, karena panen harus dilakukan pada tingkat kadar air biji tertentu pada masing-masing spesies atau varietas. Misalnya tanaman serealia dan legume dipanen pada kadar air $20 \%$. Umumnya kadar air tertinggi untuk panen adalah $30 \%$, supaya awet (Copeland and Mc. Donald, 1985), kecuali bila biji disimpan. Kadar air yang tinggi akan memacu tumbuhnya mikroba.

Pengaruh varietas dan umur panen terhadap kandungan protein, lemak, dan karbohidrat biji kacang tanah ditunjukkan pada tabel 1. Ada interaksi antara varietas dan umur panen biji dalam mempengaruhi komposisi kimia biji tersebut. Komposisi kimia dalam biji selalu berubah selama perkembangan biji, dan ini sesuai dengan pendapat Copeland dan Mc. Donald (1985). Gardner et. al. (1985) juga mengatakan bahwa komposisi kimia pada biji lebih besar daripada bagian vegetatif.

Kadar protein biji varietas Lokal tidak berbeda nyata dengan varietas Gajah. Perbedaannya hanya terdapat pada faktor umur biji. Kadar protein maksimum dicapai pada umur 55, 73 HSB. Menurut Gardner et al. (1985), protein merupakan polimer asam amino yang dihubungkan dengan ikatan peptida. Asam amino-asam amino tersebut terdapat di alam, sebagian atau seluruhnya dapat terangkai dengan urutan yang bervariasi membentuk molekul protein yang berbeda.

Secara fisiologis protein merupakan matrik kehidupan dalam biji dan sel hidup lainnya; sedangkan lemak dan karbohidrat merupakan cadangan energi yang utama pada sebagian besar tanaman. Kandungan lemak tertinggi pada varietas Gajah, $45 \%$ dan varietas Lokal hanya $44 \%$. Asam lemak dalam biji kacang tanah umumnya asam lemak tak jenuh sehingga mudah mengalami oksidasi menghasilkan peroksida, aldehid dan keton (Woodroof, 1983). Seiring bertambahnya umur biji, kandungan lemak juga meningkat sampai maksimum. Adanya penurunan kandungan lemak pada umur 61 HSB diduga karena adanya perombakan cadangan makanan pada kotiledon padahal transfer dan pembentukan sudah dihentikan. Kadar karbohidrat awalnya menurun sampai titik minimum kemudian meningkat lagi. Menurut Nagaraj (1988), karbohidrat dalam bentuk gula reduksi merupakan gula yang siap digunakan sebagai sumber energi.

Hasil regresi tentang hubungan antara umur panen dengan parameter kadar air, kadar protein, kadar lemak, dan kadar karbohidrat disajikan pada Gambar 1 sampai 4. Analisis regresi dapat juga untuk mengetahui kadar maksimum atau minimum suatu parameter. Persamaan regresi untuk kadar air pada varietas Gajah maupun Lokal yang tidak berbeda nyata adalah: $\quad \mathrm{Y}=-11,72+2,36 \mathrm{x}-$ $0,028 \mathrm{x}^{2}$. Kadar air maksimum dicapai pada umur 42,05 HSB. Pada Gambar 2. kadar protein varietas Gajah dan Lokal tidak berbeda nyata sehingga persamaan regresi digabung menjadi $\mathrm{y}=18,3006+0,3924 \mathrm{x}-0,0036 \mathrm{x}^{2}$. Kadar protein maksimum dicapai pada umur 
55,73 HSB. Pada Gambar 3, persamaan regresi untuk kadar lemak varietas Gajah adalah $\mathrm{Y}=-7,613+2,1134 \mathrm{x}-0,0212 \mathrm{x}^{2}$, kadar lemak maksimum pada umur 49,51 HSB, persamaan regresi varietas Lokal adalah y $=-10,8772+2,2310 \mathrm{x}-0,0234 \mathrm{x}^{2,}$ kadar lemak maksimum pada umur 47,73 HSB. Persamaan regresi untuk kadar karbohidrat (Gambar 4) biji varietas Gajah adalah $\mathrm{Y}=-57,8772+2,2310 \mathrm{x}-0,0151 \mathrm{x}^{2}$, kadar karbohidrat minimum pada umur 50,17 HSB, sedangkan persamaan regresi varietas lokal adalah : $\mathrm{y}=-64,7195+1,8805 \mathrm{x}-0,0208 \mathrm{x}^{2}$, kadar karbohidrat minimum pada umur 42,20 HSB. Secara statistik, hanya pada kandungan lemak dan karbohidrat, dua varietas berbeda nyata. Namun demikian, pola kenaikan maupun penurunannya hampir sama, bahkan juga pada hubungan antara umur panen dengan kadar air maupun kadar protein biji. Pola tersebut pada awalnya rendah, lalu meningkat dan akhirnya turun walaupun hanya sedikit. Bila biji akan digunakan sebagai benih maka saat berat kering maksimum merupakan saat yang tepat dipanen untuk mendapatkan kualitas benih yang tinggi. Namun bila digunakan untuk konsumsi, ketentuan tersebut tidak berlaku. Artinya, kacang tanah dapat dipanen sesuai dengan keperluan.

\section{Kesimpulan}

Berdasarkan hasil penelitian, dapat diambil kesimpulan bahwa umur panen biji sangat berpengaruh terhadap kadar air, kadar protein, kadar lemak, dan kadar karbohidrat biji. Pada umur biji 26 HSB, kadar zat gizi tersebut rendah, kemudian meningkat mencapai maksimum pada umur yang lebih tua, lalu turun pada akhir panen (61 HSB); baik pada varietas Gajah maupun Lokal.

\section{Daftar Pustaka}

Anonim. 1995. Daftar Komposisi Bahan Makanan. Direktorat Gizi, Departemen Kesehatan RI. Bhratara Karya Aksara Jakarta.

Chamma, H.M.C.P., Marcos-Filho, J. and Crocono, O.J., 1990. Maturation of Seeds of 'Aroana' beans (Phaseolus vulgaris L.) and its influence on the storage potential. Seed Science and Technology $18: 371-382$.

Copeland, L.O. and M.B. Mc Donald, 1985, Principles of Seed Science and Technology. Macmillan Publ. Co. New York

Gardner, F.P., R.B. Pearce, and R.L. Mitchell. 1985. Physiology of Crop Plants. The Iowa State University Press.

Gomez, K.A. and A.A. Gomez, 1983. Statistical Procedures for Agricultural Research. Second Edition. An International Rice Research Institut Book John Wiley \& Sons, Los Banos.

Nagaraj, G. 1988. Chemistry and Utilation. In P.S. Reddy (Edt). Groundnut. pp 555 565.Indian Council of Agricultural Research. Krishi Anusandhan Bharan, Pusa, New Delhi

Trustinah, 1993. Biologi Kacang Tanah. Dalam Monograf Kacang Tanah. Hal.: 9-23. Balai Penelitian Tanaman Pangan, Malang,

Woodroof, J.G., 1983. Peanut Production, Processing, Product. Third Edition. AVI Publishing Company, Inc. Westport. Connecticut. 
Tabel 1. Rerata Kadar Air, Protein, Lemak, dan Karbohidrat Biji Kacang Tanah Varietas Gajah dan Lokal Pada Berbagai Umur Panen (\%)

\begin{tabular}{lccccc}
\hline Varietas & Umur Panen (HSB) & Kadar air & Protein & Lemak & Karbohidrat \\
\hline \hline Gajah & 26 & 31.338 & $25.841 \mathrm{~g}$ & $32.890 \mathrm{M}$ & $28.620 \mathrm{p}$ \\
& 31 & 29.533 & $27.219 \mathrm{f}$ & $38.233 \mathrm{I}$ & $25.819 \mathrm{qr}$ \\
& 36 & 40.123 & $27.720 \mathrm{ef}$ & $40.881 \mathrm{G}$ & $22.122 \mathrm{~s}$ \\
& 41 & 38.940 & $28.065 \mathrm{def}$ & $42.231 \mathrm{E}$ & $22.411 \mathrm{~s}$ \\
& 46 & 37.027 & $28.358 \mathrm{de}$ & $44.800 \mathrm{~B}$ & $20.673 \mathrm{tu}$ \\
& 51 & 34.620 & $28.496 \mathrm{de}$ & $45.438 \mathrm{~A}$ & $20.349 \mathrm{u}$ \\
& 56 & 31.323 & $29.523 \mathrm{abc}$ & $45.603 \mathrm{~A}$ & $18.053 \mathrm{v}$ \\
& 61 & 21.000 & $29.610 \mathrm{ab}$ & $41.589 \mathrm{~F}$ & $23.121 \mathrm{~s}$ \\
\hline Lokal & 32.393 & $25.823 \mathrm{~g}$ & $32.807 \mathrm{M}$ & $29.265 \mathrm{p}$ \\
& 26 & 29,733 & $27.854 \mathrm{f}$ & $35.128 \mathrm{~L}$ & $25.465 \mathrm{r}$ \\
& 31 & 40.510 & $27.871 \mathrm{ef}$ & $36.415 \mathrm{~K}$ & $26.873 \mathrm{q}$ \\
& 36 & 36.793 & $28.041 \mathrm{def}$ & $41.765 \mathrm{~F}$ & $22.991 \mathrm{~s}$ \\
& 41 & 34.143 & $29.722 \mathrm{ab}$ & $42.920 \mathrm{D}$ & $21.836 \mathrm{st}$ \\
& 46 & 30.957 & $28.903 \mathrm{a}$ & $44.349 \mathrm{C}$ & $20.434 \mathrm{u}$ \\
& 51 & 28.553 & $28,683 \mathrm{cde}$ & $37.518 \mathrm{~J}$ & $28.957 \mathrm{r}$ \\
& 56 & $(-)$ & $(+)$ & $(+)$ & $(+)$ \\
\hline
\end{tabular}

Keterangan :

Angka dalam kolom yang diikuti huruf yang sama tidak berbeda nyata pada uji Duncan 5\%.

$(+)$ : ada interaksi

$(-)$ : tidak ada interaksi 


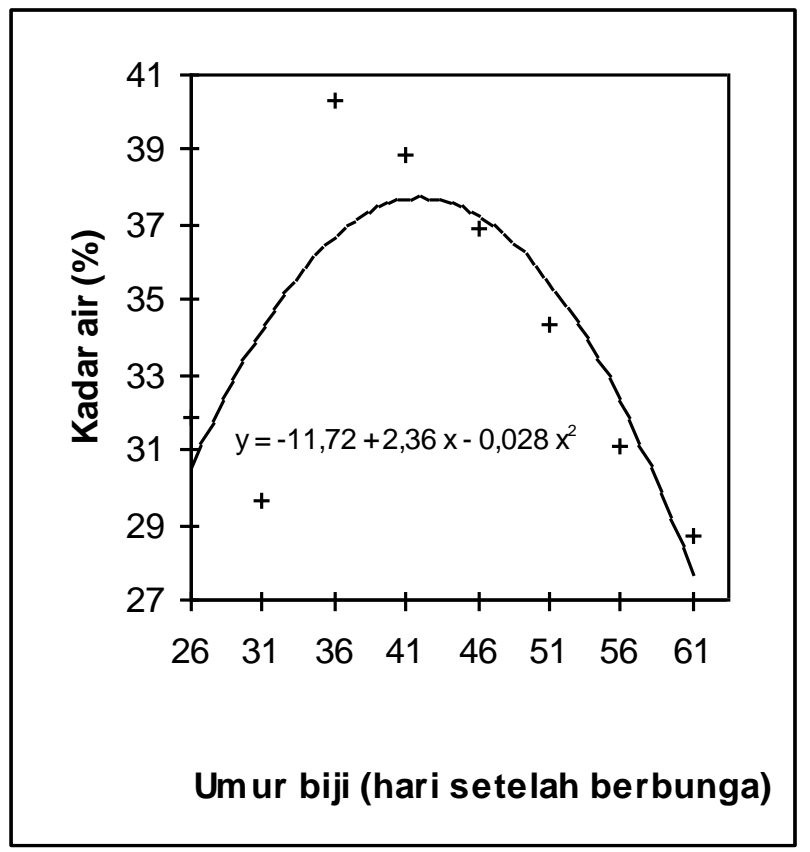

Gambar 1. Hubungan antara umur panen dengan kadar air

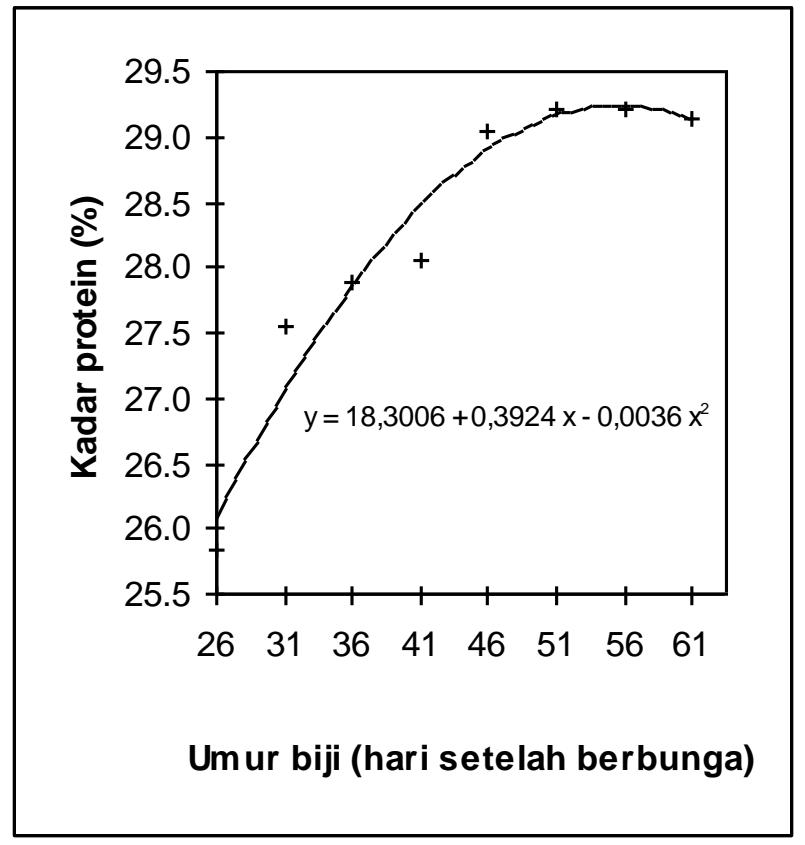

Gambar 2. Hubungan antara umur panen dengan kadar protein 


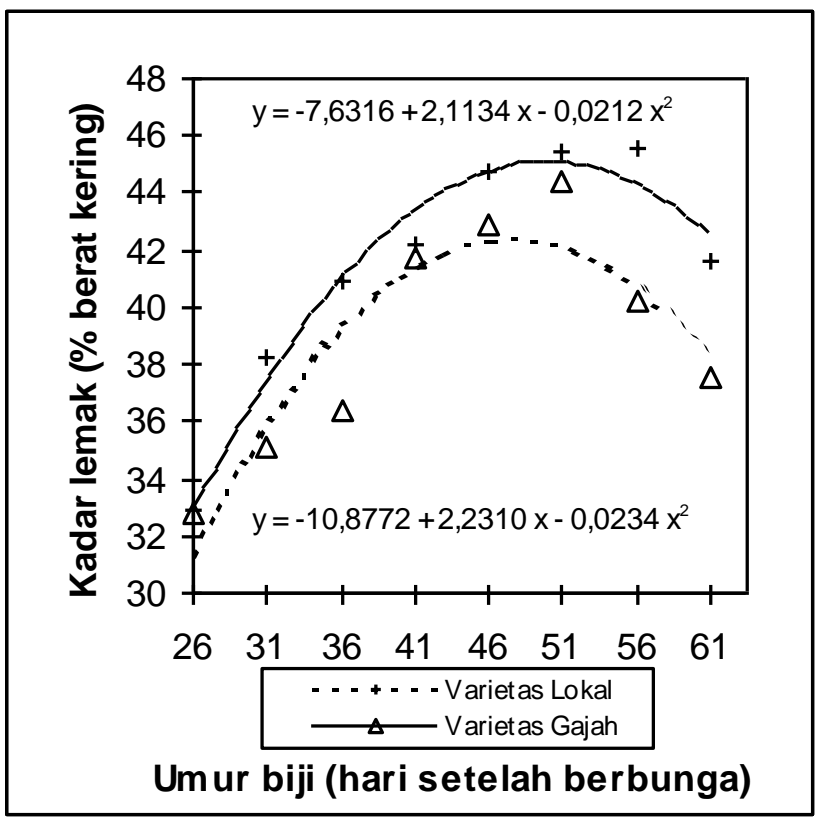

Gambar 3. Hubungan antara umur panen dengan kadar lemak

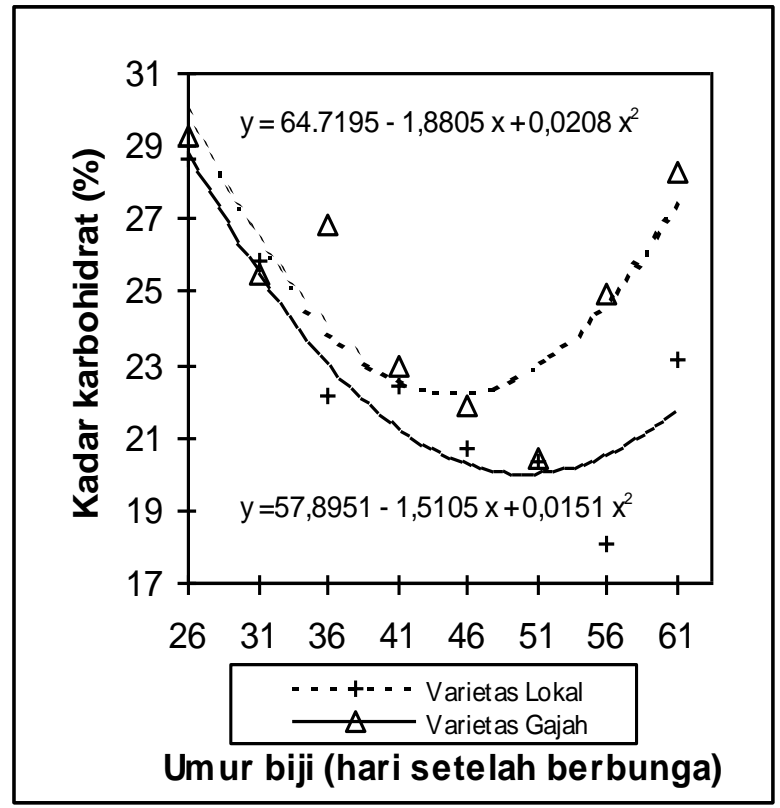

Gambar 4. Hubungan antara umur panen dengan kadar karbohidrat 